\title{
Responding to Clients and Students Regarding the Existence of $\mathrm{God}^{1}$ Stuart Nicolson
}

\begin{abstract}
This article considers where, for example, through situations enabled by caritas or diakonia, a client or student asks a professional for reasons for believing in the existence of God, whether seeking to rationalise his beliefs, to support a fading belief, as a genuine question, or as a sceptical test. The onus, according to Scripture and the Second Vatican Council, is on the Christian to be prepared to offer an explanation for his belief and to do so in a Christian manner. This article looks at the various different types of responses to such a question, which can be grouped as objective, subjective, or a combination of both, based upon work by Peter Kreeft and includes some commentary regarding this particular situation. These approaches include classical explanations, personal considerations, and one's own experience. In approaching the question in various manners, clients or students who hold a position such as postmodern relativism, fideism, or have little belief in God can be answered. In being able to offer such answers, the professional can provide a suitable response when asked about God's existence in situations offering care or education in a context enabled by caritas or diakonia.
\end{abstract}

Keywords: existence of God, questions, responses, postmodern relativism, Second Vatican Council, caritas, diakonia, education, Peter Kreeft, apologetics

\section{Introduction}

The key areas in pastoral theology of caritas or diakonia open up in the world many opportunities to present the goodness of Christianity, the sacrifices made by Christians, and the love of God. Such an example of giving, sometimes without financial reward, is a strong witness to some. It is such acts that can lead a client of social work or care, or a student in an educational context, to ask the professional who is providing a service with a caritas or diakonia context why he believes in God. This question may be asked in a simple or a challenging way, in a friendly or testing manner, and in a way seeking support for dwindling or fledgling faith, or to try to prove the Christian wrong. Regardless of the reasons and manner of the question of 'Why do you believe in God?' or 'Why should I believe in God?', it is the responsibility of the Christian to be prepared to offer a reasoned answer for such a belief, as set out in Scripture and in the texts of the Second Vatican Council.

1 This work was supported by GAJU [157/H/2016]. 
Peter Kreeft offers twenty such responses, which can be categorised in three ways: objective, subjective, and a combination of objective/subjective. The objective proofs are generally the classical set of proofs which are more philosophical yet are accessible and can be explained without great problem. The subjective proofs consider the personal experience of the recipient of the answer. And the combined set uses elements of both of these. It must be considered that there is no magical answer, that all of these should be thought over and are best discussed, and that it is better to offer more than one of these responses to the one asking the question. In fact, it is reasonable that several of these answers, working together to show harmony and consistency, can be more effective in removing doubts regarding the existence of God, and to show that such a belief is rational. Therefore, in the professional caritas or diakonia context, or indeed in any walk of life, the Christian can offer reasons for the existence of God to those who question this, whether for reasons of doubt or to challenge faith.

This article will briefly describe each of Kreeft's reasons while commenting on them and offering thoughts for use in a caritas or diakonia context. Reading Kreeft's text itself is highly recommended for further depth, detail, and sometimes clarity. However, this brief overview with some explanations can serve to provide both a taster of Kreeft's longer and more detailed text (albeit still quite approachable) as well as provide some responses for the professional who prefers a briefer source in order to be prepared to respond to questions about God's existence

\section{Context and suitability of offering a response}

St Paul's way of meeting people and starting up conversations was often through his work as a tentmaker. This was a means not only to support himself and remain grounded but also his way of creating opportunities to engage people in talking about God, Jesus, and the early Church. There are many reasons one today may choose to work in services such as social work, caring for others, or education, and in some cases the financial benefit of such work is low or even non-existent. In both caritas and diakonia -generally speaking, serving for the sake of love - it is about doing something for God and for neighbour. And even if evangelisation is not the aim (for some Christians a frightening idea!), the possibility exists of the social worker, carer, or educator (henceforth professional) being asked to give a reason for believing in the existence of God. It is possible that the client, patient, or student (henceforth recipient) is genuinely curious about what causes people to engage in such work, or why someone wears a crucifix as jewellery; perhaps the faith of the professional and the institution is clear and the recipient seeks to strengthen his struggling faith; or maybe the recipient knows the faith of the professional and seeks to challenge this, whether negatively or with some positivity. Regardless of the reasons for the question and the manner in which they are asked, for the Christian this is an opportunity to present the existence of God not only as an act of faith but also a rational way of thinking, for faith must be compatible with reason if it is to avoid being fideistic ${ }^{2}$ or even mere superstition. ${ }^{3}$

Christians are called to be ready to respond when they are asked about their faith. Two of the most powerful calls come from Scripture and from the Second Vatican Council. In fact, the wording in both of these is quite similar. St Peter states that we should

2 ( JOHN PAUL II, Fides et Ratio (online), available from: http://w2.vatican.va/content/john-paul-ii/en/encyclicals/documents/hf_jpii_enc_14091998_fides-et-ratio.html, cited $20^{\text {th }}$ December 2018, 52, 53, 55.

3 Ibid., 36, 37, 48, 52. 
Always be prepared to make a defence to anyone who calls you to account for the hope that is in you, yet do it with gentleness and reverence; and keep your conscience clear, so that, when you are abused, those who revile your good behaviour in Christ may be put to shame. (1Pt 3:15-16)

This is a three-fold call: first, of being prepared to respond to questions regarding why to have belief in God and in Christ; second, to respond when questioned; and third, that this is done so in a Christian manner. This call is repeated in Lumen gentium (which cites the 1 Peter quote) and expanded upon and strengthened in Dignitatis humanae:

Everywhere on earth [all disciples of Christ] must bear witness to Christ and give an answer to those who seek an account of that hope of eternal life which is in them. (LG 10)

The disciple has a grave obligation to Christ, his Master, to grow daily in his knowledge of the truth he has received from him, to be faithful in announcing it, and vigorous in defending it without having recourse to methods which are contrary to the spirit of the Gospel. (DH 14) ${ }^{5}$

Within the two conciliar quotes, even being somewhat similar in language, the three-fold call of St Peter can be clearly seen: we should always be ready to respond when asked about why we have faith and we should do it in a Christian manner, that is, in a respectful manner consistent with love for one's neighbour. The council in Gaudium et spes spoke also specifically to theologians to support the development of opportunities for this to take place, which therefore includes caritas and diakonia studies: 'theologians, within the requirements and methods proper to theology, are invited to seek continually for more suitable ways of communicating doctrine to the men of their times.' ${ }^{6}$

The Petrine quote was the foundation of apologetics in the early Church. Over the centuries, and in many different contexts, the field of apologetics changed, often becoming more estranged from its original purpose and style. ${ }^{7}$ But in the past few decades, a new apologetics has developed, consistent with the Scriptural and conciliar calls. This new style of apologetics was promoted by William Levada, ${ }^{8}$ a key cardinal under Pope Benedict XVI, and is encouraged by Pope Francis. ${ }^{9}$ Indeed, Pope Benedict stated that while charity is not merely a means of proselytising, 'this does not mean that charitable activity must somehow leave God and Christ aside' and that

the best defence of God and man consists precisely in love. It is the responsibility of the Church's charitable organizations to reinforce this awareness in their members, so that by their activity-as well as their words, their silence, their example - they may be credible witnesses to Christ. ${ }^{10}$

4 (C) Lumen gentium (online), available from: http://www.vatican.va/archive/hist_councils/ii_vatican_council/ documents/vat-ii_ const_19641121_lumen-gentium_en.html, cited 20 $0^{\text {th }}$ December 2018.

5 Dignitatis humanae, in Glenn B. SINISCALCHI, Retrieving Apologetics, Eugene (OR): Pickwick, 2016, p. 18. This translation of the Vatican II text is clearer than the official online version, while remaining faithful to the meaning of the version on the Vatican website.

6 (c) Gaudium et spes (online), available from: http://www.vatican.va/archive/hist_councils/ii_vatican_council/ documents/vat-ii_ const_19651207_gaudium-et-spes_en.html, cited $20^{\text {th }}$ December 2018, 62.

7 Cf. Stuart NICOLSON, The Field of Apologetics Today: Responding to the Calls of Scripture and the Second Vatican Council, Heythrop Journal Vol. 59 No. 3 May 2018, pp. 410-423.

8 (C) William LEVADA, The Urgency of a New Apologetics for the Church in the 21st Century (online), available from: http://www.vatican.va/ roman_curia/congregations/cfaith/documents/rc_con_cfaith_doc_20100429_levada-new-apologetics_en.html, cited $20^{\text {th }}$ December 2018.

9 For example, in Evangelii Gaudium 132. This excerpt and further clarification of Pope Francis' position on apologetics is presented in (C) Jimmy AKIN, Did Pope Francis just diss apologists? 9 things to know and share (online), available from: http://www.ncregister.com/blog/ jimmy-akin/did-pope-francis-just-diss-apologists-9-things-to-know-and-share, cited $20^{\text {th }}$ December 2018.

10 (c) BENEDICT XVI, Deus caritas est (online), available from: http://w2.vatican.va/content/benedict-xvi/en/encyclicals/documents/hf_ ben-xvi_enc_20051225_deus-caritas-est.html, cited 20 $0^{\text {th }}$ December 2018, 31. 
Therefore, it is clear that the modern context of reaching out, sometimes through caritas and diakonia in action, often leads to occasions where the original meaning of Peter, captured clearly by the council, is the appropriate action of the Christian. However, the third part of Peter's call must be followed - to do so in the way of loving one's neighbour, which has so often been overlooked in apologetics in the past. By recalling and ensuring this, the professional's response is both consistent with and an extension of the caritas or diakonia taking place.

Yet it is the first part of the call - to be prepared to respond - which often causes an issue for the Christian professional. Today, there is a large number of sources of information, many of them online, but these are often not easy for the non-specialist to access due to ease of language, specialist terms, or time and energy constraints. Therefore, sources such as Peter Kreeft's Twenty Arguments for the Existence of $\mathrm{God}^{11}$ are very helpful due to accessibility and readability. The thinking behind offering a number of reasons, or arguments, for the existence of God is that different reasons appeal to different people, partly due to pre-existing beliefs held, such as atheism, postmodern relativism, or a spiritual feeling that is against what is regarded as institutionalised religion. Nevertheless, it is better to be prepared for such possibilities.

Regardless of the reason for the question, though, it is important not to allow the conversation to turn into a heated debate or confrontation, and it is quite possible that while the Christian 'wins' such an argument this can lead to giving the wrong impression that Christian faith is forced. Instead, sowing seeds of possible faith, or supporting a Christian with doubts, is the aim of the Christian in such a professional situation, where it may even seem that Christian faith is rejected - ideas sown, like plant seeds, can take a while to show any growth, whether in the recipient or in any witnesses to the conversation. The professional in such a situation must also remember to respect and work within the rules if their caritas- or diakonia-based work is for a non-Christian organisation; however, if one is asked in such a situation for reasons for faith in the existence of God then it is reasonable to expect that the professional can reply using discretion. This article will continue by presenting - mostly through summarising - exploring, and commenting on the arguments offered by Kreeft, having been split into three groups regarding their content, thus making them more usable to the professional. By being aware of how at least some of these work, the professional can offer one or more of these responses when questioned regarding the existence of God.

\section{Objective reasons}

The objective arguments for the existence of God, or reasons for believing God exists, that Kreeft offers are nine in total. These can be grouped into standard, classical arguments with some of their roots in Aristotle (Kreeft's first seven are, relate to, or are explanations of Aquinas' five ways (viae), which argue for the existence of God) and two other arguments. For some recipients, a clear explanation of one or more of these reasons is sufficient reason to believe in God, however, there are some counter arguments that have been devised to 'muddy their waters. ${ }^{12}$ Nevertheless, these

11 Peter J. KREEFT and Ronald K. TACELLI, Handbook of Catholic Apologetics, San Francisco: Ignatius Press, 1994, pp. 52-92. This complete text is also available online at https://strangenotions.com/god-exists/. As it is credited to Kreeft alone online, it is presumed here that this section in the book was written by Kreeft alone.

12 While this paper focuses on how to present Kreeft's reasons for believing in God's existence, which are for a more general audience, Edward Feser's works are highly recommended for those interested in a more robust level of objective arguments. For objective proofs of God's existence, cf. Edward FESER, Five Proofs of the Existence of God, San Francisco: Ignatius Press, 2017. Regarding dealing with the claims of the 'New Atheists', cf. Edward FESER, The Last Superstition, South Bend (IN): St. Augustine's Press, 2008. 
reasons can be presented usually without any real problems.

Kreeft's first reason regards Change. We are all in changing states. Nothing in our universe is not changing - growing, shrinking, developing, fading, and so on. These changes are caused by something else - cell growth, emotions and thoughts, destruction by an agent, etc.; thus, nothing can change its very self, which means there must have been a First Changer. The First Changer cannot be changed (or it would have had a pre-first changer, which makes no sense) so it is therefore always constant and unchanging. That First Changer who never changes is God, 'the unchanging Source of change. ${ }^{13}$

The second reason of Kreeft is Efficient Causality. It is similar to the first reason but focuses on cause and effect. My thirst causes me to drink, my desire to progress causes me to work, parents cause children to exist, and hopefully cause children to thrive... The universe causes me to do many things, including continue to exist. I am dependent on the universe of a huge number of interacting causes. Everything in the universe is caused by something else, but there must have been a First Cause, outside of the material universe. That First Cause is God. Kreeft likens existence to a gift, handed on through the generations. Someone must have handed on that gift of existence the first time, someone whose existence never stops (and indeed also never started), someone who always is: God said to Moses that his name is 'I am who I am' (Ex 3:14) and Jesus said 'Before Abraham was born, I am' (Jn 8:58).

In this part, Kreeft also answers two questions that argue that this argument does not work. He answers that we need an uncaused cause (and not just mutual causing constantly) because there needs, in time, to be a first giving of the gift. Equally, this could be likened to balls being juggled in the air but never having been thrown up in the first place. The second question regards an endless list of causes going back in time, which is dealt with in Kreeft's seventh argument section. Simply, no matter how long that 'endless' list is, it could technically be traced back to that first cause, when something happened the first time; everything in this universe has a beginning and an end so that First Cause must be God, who is outside the universe.

Kreeft's third, from Time and Contingency, is about existence. Things start to exist then later do not exist, such as a plant or an animal. We are all like this, with a beginning and an end. If everything is like this then over a huge amount of time, everything would cease to exist, but it has not happened. Therefore, something has the built-in property of existence, that is, it always exists and cannot not-exist and that 'being' is God. Kreeft use Aquinas's term here: God is a 'necessary' being. ${ }^{14}$ On its own, the third reason can be quite 'theoretical' but when it is used alongside the first or second reason, they can work together effectively: there is a First Cause/Changer who must necessarily exist. Then things cause each other in a chain; if everything happens to stop existing without further causes then nothing will exist to cause other things to exist. The first three reasons build a specific image together, however, the following reasons for believing in God's existence change to a different style.

The fourth of Kreeft's reasons regards Degrees of Perfection. Kreeft's examples are lighter/darker, hotter/colder, more or less loving. He moves to stating that a stable way of being is better than unstable, which is at risk of not being. And of course, being is better than not-being, which connected with positive ideas shows degrees of perfection: it is better to be more loving, more intelligent, more generous... Take all of these hierarchies of being up to the point of perfection and there we find God. Kreeft does include the objection that this argument presumes that there is a hierarchy 
of being better or worse but that this is merely subjective; he points out that the questioner here clearly considers that it is better to ask that question than not to do so, which makes 'asking it better than not asking it', and receiving an answer better than it being ignored. Kreeft therefore cleverly points out: 'You can speak subjectivism but you cannot live it.' ${ }^{\text {'5 }}$ In other words, it's a nice idea but it doesn't affect (objective) reality.

One further benefit of offering reasons for the existence of God is that they show different attributes of the Judaeo-Christian (theistic) God. The first three reasons simply show that a First Changer/ Cause is also a necessary being regarding existence. For some, this points to a deistic God, such as the supposed Newton's Watchmaker, ${ }^{16}$ that is, God created the universe, set it working, and it has worked entirely independently of him ever since. But research has shown that, nevertheless, Kreeft's fourth reason for believing in the existence of God begins to offer some ideas about what God is like, such as perfectly loving, perfectly giving, and perfect in all other ways, and if Jesus is indeed divine, this means God was not content to leave his Creation alone but to enter our world as Jesus the God-man, and perhaps intervene in other ways also.

The fifth reason offered by Kreeft is about Design and is effective because 'reflection on the order and beauty of nature touches something very deep within us. ${ }^{\prime 17}$ It also regards issues that are considered 'Darwinian'; however, the idea that natural selection takes place is obvious and here the evolution of species is not involved so, no matter the position of the professional or the recipient, the only two possible positions in discussing this argument are that there was an intelligent Designer who created the universe in such a way or it occurred purely by chance to become and develop to the point of where we are today. If we can perceive design then there must be a designer. Even if we consider natural laws to be the designer itself, who designed them? But if the recipient is determined in their position not to accept intelligent design then the whole conversation can be derailed into this debate. It is better then for the professional to offer at this point other reasons for the existence of God. However, if the recipient is determined to discuss these issues, there are other texts ${ }^{18}$ that are useful for the professional for research.

The sixth reason given by Kreeft is the Kalam argument, which is a modern formulation of a medieval Islamic argument, showing that there cannot be an infinite number of causes in the universe, and therefore there is a First Cause of the existence of the universe (and ultimately in the present, you the reader), similar to the second reason on Kreeft's list: this is indeed a version of the second reason but with a slightly different focus. Kreeft also uses this section to tidy up a few loose ends of responses against the reasons so far and this makes it a worthwhile section to read if a professional wants to develop an understanding of the philosophical debates regarding these issues.

The seventh reason points out that for something to exist, those things necessary for it to exist must also exist (or have existed). As with other reasons, we can work backwards and outwards to say that everything in the universe has been enabled by other things to exist, and therefore the universe must have an outside cause to exist, which is what we consider to be God. Of

15 Ibid., p. 59.

16 Research has shown that this particular image is untrue. Newton did not believe in a deistic God and was a normal Judaeo-Christian believer in all but one very important aspect: he did not believe Jesus to be divine, meaning he was an Arian thinker, in agreement with the followers of Arius of the fourth century. This, Newton kept quiet about, due to it being a very problematic belief in his own time, which led some Enlightenment thinkers later to interpret him as a deist. Cf. Edward B. DAVIS, That Isaac Newton's Mechanistic Cosmology Eliminated the Need for God in: Ronald L. NUMBERS (ed.) Galileo Goes to Jail and Other Myths about Science and Religion, Cambridge (Mass.) and London: Harvard University Press, 2009, Myth 13, pp. 115-23, especially pp 116-8.

17 KREEFT and TACELLI, pp. 59-60.

18 For example, cf. Scott HAHN and Benjamin WIKER, Answering the New Atheism, Steubenville (OH): Emmaus Road Publishing, 2008. 
course, the idea of a previous universe and ones before that ad infinitum can be a counter argument, but this infinite regress is simply more steps on that ladder of previous causes that must surely have a First Cause.

It is clear that the seventh reason offered by Kreeft is similar to several before in different versions (first, second, third, sixth) and that most of the ideas so far are fairly alike, but it is that consistency with variability in the details of the methods of thinking that show that this is not one idea which has no support but that it is a robust concept that describes the reality of the origins of our existence. Similarly, if a tree grows out of the ground, we can look at it from any angle and it is still a tree, but if it is a picture of a tree then it will not be consistent from all angles. The strength of the reasons for believing in God's existence so far are strong in that they work together well, painting a consistent image.

The eighth reason of Kreeft's is the World as an Interacting Whole, which uses elements of the third and fourth somewhat but especially the fifth. As all component parts within the universe play some role, and 'no component part or active element can be self-sufficient or self-explanatory, ${ }^{19}$ everything is relational and part of the whole. Furthermore, the whole (the universe) has no meaning or explanation in itself for its existence. Therefore, for this to exist in such a dynamic and seemingly meaningful way, it must have an intelligent, external cause to explain it, which we can consider as God. This, of course, can tap into the idea of 'Why are we here?', which cannot be answered by modern secular thinking that reduces everything to mere physical existence. Indeed, the physical when examined points to something more.

The final objective reason for God's existence being rational is Miracles. By definition, this is an action of God against the normal laws of nature, that is, a supernatural occurrence. The clearest example for Christians is the Resurrection: without this supernatural action, there is no Christianity. There are many more examples with Judaeo-Christianity, which shows that, as there is no possible natural cause for a particular phenomenon or occurrence, God must be the cause. However, this is an area completely rejected by many as merely a phenomenon or occurrence that cannot be explained by today's scientific understanding. This rightly includes many aspects that cannot be explained in the contemporary time, such as a flying machine in the seventeenth century, which by the twentieth century was common-place. Yet, we must consider also miracles in their contemporary time. The image on the Shroud of Turin was created by a means still definitely unknown today. ${ }^{20}$ As it is entirely unexplainable still, but was created many centuries ago at least, this means that either it is a genuine act of God or it is a forgery created long ago by time-travelling tricksters or aliens with superior technology. While a few may find the latter two reasons appealing, there are no other good reasons to believe in them, but there are many reasons for believing in God. Therefore, not only does an outright rejection of miracles go against the evidence, it also says that God is restricted to merely a passive (deistic) role in his Creation, which means that Jesus was not divine and more or less means everything has a positivistic, materialistic cause. Nevertheless, as Kreeft points out quite correctly, the reason of Miracles is not a proof, but a very powerful clue or sign.'21

Thus, the objective reasons for believing in the existence of God have mainly classical and some modern sources, and they consider philosophical and some scientific aspects as they regard 'external' reasons for belief. They stand alone to various extents but work together effectively and sometimes complement each other so well that they can develop into a stronger reason for

19 KREEFT and TACELLI, p. 68.

20 Cf. ( ) John P. JACKSON, Is the image on the Shroud due to a process heretofore unknown to modern science? (online), available from: http:// www.shroudofturin.com/Resources/ShroudFallThroughSDTV2.0.pdf, cited 22 ${ }^{\text {nd }}$ December 2018, especially Appendix C., pp. 22-5.

21 KREEFT and TACELLI, p. 71. 
believing in God's existence. By presenting more than one of these, depending on level of interest and depth of understanding held, the professional can present effective objective reasons when asked to explain why they think God exists. However, objective thinking can be combined with subjective thinking and experience also, which is considered in the next section.

\section{Objective/sulbjective reasons}

By taking elements of both objective and subjective thinking and combining them, Kreeft offers five more arguments out of his twenty. We will continue to follow his order as he gradually moves from the purest objective thinking to the most subjective considerations. Each of these reasons combine the two ways of considering the existence of God.

Kreeft's first combined reason is his tenth, that of Consciousness. It considers our experience of the elements of the eighth and therefore fifth reasons - that there is intelligence in the design of the universe that works well together - and points out that we can make sense of it. So, if we can make (some) sense of the universe, not only is it intelligible but we are capable of finding it intelligible. That is a very random fact or it is because we, and the universe, are created in such a way. This reason can of course be very effective in explaining how belief in God's existence is rational when it is used after explaining the fifth and eighth reasons. Thus, combinations of objective and semi-subjective reasons can develop people's understanding of the rational position of God's existence more easily.

Related to the previous reason, the eleventh reason regards Truth. It can be added to the Design group of reasons, whilst having a clearly subjective element. Simply, as we can understand 'eternal truths about being, ${ }^{22}$ which is what we have been doing, then 'truth properly resides in a mind'. ${ }^{23}$ As our minds are clearly not eternal (and thus the First Cause of the truths), an eternal mind is necessary. Therefore, starting from our own experience, we can show that a greater mind is necessary. Like several other reasons, this is not a particularly strong stand-alone reason, especially if the recipient is open to ideas such as hive-intelligence or a non-Christian cosmic mind concept. By beginning with this idea, the professional in this situation would find himself working backwards and arguing against other ideas to finally reach God, which is not a good apologetical approach in a pastoral and caring context.

The twelfth reason concerns the Origin of the Idea of God. Kreeft points out that Descartes used this argument, which says that our ideas must originate somewhere - from ourselves or outside of us. As we are not perfect, the idea of a prefect being must come from beyond us. As only God is perfect, we must have some inbuilt understanding of him. While the doubter might say that the concept of perfect is only an extension of perceiving imperfection, if man knew nothing of perfection, how could he invent this idea as there is no real perfection in this universe (only a contrived idea in mathematics, etc.). This reason can be used in conjunction with objective ideas - if someone states that they hold infinite regress or an infinite chain of causes as true then this argument, that the idea of a perfect being must come from a perfect being, is helpful to the professional. Further, it is clear from Religious studies and anthropology that the idea of God is common across times, races, and cultures. The idea of the distant Supreme Being, such as El in the Middle East, is ancient and crosses cultures. Thus, the perfect being is more of an instinct than philosophical speculation. 
The Ontological argument is the thirteenth reason in Kreeft's list for believing in God. Originating from St Anselm just less than a millennium ago, this has often been shown to be insufficient, but it keeps coming back as it says something powerful. It states that something real and in the mind is greater than something only in the mind; also, God is the one of whom no greater can be thought; so, if God only exists in the mind, an existing God would be greater; therefore, God (no being can be greater than him) exists in the mind and also in reality. It is not a convincing proof to the non-believer but it has its strength in that it cannot be disproved. The key issue is that if it is connected to another proof, particularly the third reason, that existence is eternal and outside the universe (and can be named as God) then it is clear that, as existence exists then God exists. In reality, if someone has a pre-determined concept of God existing then it is possible to accept the Ontological argument, but it doesn't work on its own for someone who is a convinced atheist. However, it can be added to other arguments to show belief as rationally consistent.

The fourteenth reason, and the final one of the combined group, is the Moral argument, which has a number of elements. This states that morals either come from a religious origin or a material origin. It is clear that material thinking does not in itself lead to a good moral system; modern European morals are based mainly on the Judaeo-Christian foundation from the past, albeit some destructive and unfair aspects are growing (such as euthanasia). It should also be pointed out that some societies with religion are not particularly moral for us, such as the Roman treatment of unwanted children or the treatment of young females in some societies today - although a religion exists there, it does not have a Judaeo-Christian development of morals. A popular atheist claim is that the Golden Rule (treat others as you wish to be treated) is sufficient, but one of its earliest origins is the Old Testament ('love your neighbour as yourself': Lev 19:18). Although the idea of religion is not necessarily connected to God, never mind proof of his existence - Kreeft admits that Platonic idealism suffices as a source for acceptable morals - he does find God as the likeliest origin of a moral conscience. This is probably where Kreeft is weakest in his twenty proofs: he finally mentions God in terms of love but he states there are many steps 'from objective moral values to the Creator of the universe or the triune God of love. ${ }^{24}$ However, for the Christian professional, when asked for an explanation for believing in God's existence, that God is love (Deus caritas est) and therefore has given us moral consciences, it is generally sufficient at this level of rational response.

The subjective/objective combined group of reasons for believing in God's existence consists of five different reasons that expand upon objective reasons, and thus work as an enrichment of these, or are a mix of elements concerning what is within us and that which is beyond us. As before, they work best in conjunction with others and serve to strengthen the idea that God exists and it is rational to believe in him. The final group, subjective reasons, will regard the experience of the recipient.

\section{Subjective reasons}

Kreeft offers us six subjective reasons for believing in the existence of God and these can be the most effective of all when explaining why we believe when asked by someone who thinks in a postmodern relativistic way. As such a person will consider the self as the arbiter of truth, and an individual's feelings over general truths, the starting point needs to be that person's own thoughts, experiences, and feelings when presenting the rational nature of having Christian faith.

The first reason in this group, and fifteenth overall, is Conscience, which is connected to the

24 Ibid., p. 79. 
previous one, the Moral argument. However, here, the objective element is removed and the focus is on the personal obligation to follow one's conscience. If the source of my conscience which has authority over me - comes from nature (lower than me) or from me or from society (equal to me), why does it have authority over me? Clearly, the source of my conscience is from something greater than nature, myself, and society. This source is, for many, called God and we all have a conscience to varying extents even if we do not know the source. Obviously, this reason opens up the idea of a greater power or authority. For some, it is necessary to use it with one of the earlier reasons to direct that greater authority idea towards something more than an unidentified (or unidentifiable) spiritual power or principle. Kreeft helpfully offers a number of further points and ideas in this section to clarify what he means, and these are worthwhile reading.

The sixteenth reason is Desire, referring to that feeling that all people have of wanting something more - more profound, deeper, more meaningful, more stimulating. It is something of the loss of the magical, the innocent, the wonderful that is mourned in Supertramp's The Logical Song, ${ }^{25}$ which describes growing-up as replacing that earlier feeling of wonder with the world. This reason is similar in that it shows ' $[t]$ he desire for God is written in the human heart, ${ }^{26}$ which is why man has the yearning for more: it is the yearning for God, infinite love, it is something that cannot be satiated in this world. One of the reasons that Christians often seem more at peace is that faith in God and grace from him quenches that desire somewhat. A typical cynical response to this idea is that the Christian is merely using the idea of God as a crutch, to which an answer I once heard was that 'he is not only my crutch but my wheelchair, my hospital bed, and even my whole hospital!'27 Again, this is not a precise reason, leading to a clear idea of God, but it draws the postmodern relativist thinker out of their own thinking that centres on the self to consider a higher order existence that could be God. By using the Catechism quote above, the recipient is pointed in the Christian direction, and using this reason with others is again more effective.

The seventeenth is brief, being Aesthetic Experience, reflecting Balthasar's approach. ${ }^{28}$ The reasoning, quoted in its entirety, it states: 'There is the music of Johann Sebastian Bach. Therefore there must be a God.29 There is the subjective feature in this reason that if one's appreciation of beauty is not so centred on Bach's music, the source of the beauty perceived can be substituted. In other words, that beauty exists means there is a source of that beauty, a source that is far greater, a Creator. As Kreeft remarks in the third and final sentence in this short section, 'You either see this one or you don't.. ${ }^{30}$

The eighteenth reason is from Religious Experience. This says that everyone with religious faith has some level or degree of religious experience and as this is basically a universal truth, regardless of what that religious experience is, there must be some kind of source of religious existence that this stems from. Of course, religious experience can have other causes, some with deceitful intent

25 This song describes growing-up as replacing that earlier feeling of wonder with the world we can vaguely remember from early childhood, which it briefly captures in the first verse: 'When I was young, It seemed that life was so wonderful, A miracle, oh it was beautiful, magical. And all the birds in the trees, Well they'd be singing so happily, Oh joyfully, oh playfully watching me'. Available at: https://www.azlyrics.com/lyrics/ supertramp/logicalsong.html.

26 Catechism of the Catholic Church (henceforth @ C CCC, also available at http://www.vatican.va/archive/ ENG0015/_INDEX.HTM), London: Burns and Oates, 2000, 27.

27 I do not recall the verbal source and the quote is paraphrased.

28 While the common path of transcendentals was to know truth, from which goodness then beauty are recognised, Hans Urs von Balthasar begins with beauty, from which goodness can be perceived, then truth in his 16-volume 'Trilogy'.

29 KREEFT and TACELLI, p. 87.

30 Ibid. 
and others simply from delusion. But we should not deny the experience of a very large number of people throughout the world and throughout history who have had religious experience. Simply, they can't be all wrong. This is clearly not a firm logical claim but a call to appreciate the experience of a great number of people and not to deny them or reject them without good reason. As with previous subjective arguments, it is about moving the recipient beyond limited personal experience being the only arbiter of what is truth and appreciating that a very common and consistent truth for others might indeed be more objectively accurate.

Following on from the previous argument, and tightening the idea into a more logical form, is the nineteenth reason for believing that God exists: the Common Consent argument. This states that belief in God is common to a great number of people, including over time; either they are all wrong or they are not; it is surely likely that all of these people are not wrong; therefore, it is more likely that God exists. Again, this is not a sound proof of God's existence, and a cynic would give it no credibility. But here we are trying to draw the strongly subjective thinker out of this position and give credit to a widely-held position of others, which is so common it must have some credence, almost in a semi-democratic way (the professional must clarify here that he is considering a deeply held belief, though, not a political opinion).

These subjective reasons for believing in God all do not have the same rational strength as the previous ones, nor do they point so effectively at God himself, for each of them are about extracting the postmodern relativistic thinker from thought processes that are centred on the self as the arbiter of truth and provide a flavour of the truth as indeed objective, which then can point to God being the source of truth. If these are not effective then Kreeft offers one more reason for believing in God's existence, which is not an argument as such but a very subjectively oriented consideration.

Kreeft's final offering of his reasons to believe in God's existence is Pascal's Wager. As there is no clear, concise proof that cannot be ignored that God exists, the Wager focuses somewhat on self-interest. Simply put, if one believes in God and is correct, one wins eternal happiness; if one believes in God and is incorrect, there is nothing; if one does not believe in God and is correct, there is nothing; but if one does not believe in God and is incorrect, one loses eternal happiness. Kreeft acknowledges that the 'Wager can seem offensively venal and purely selfish." ${ }^{31}$ But as he points out, used properly, it can help lead someone to faith:

The Wager cannot-or should not-coerce belief. But it can be an incentive for us to search for God, to study and restudy the arguments that seek to show that there is Something-or Someone-who is the ultimate explanation of the universe and of my life. It could at lease motivate 'The Prayer of the Skeptic': 'God, I don't know whether you exist or not, but if you do, please show me who you are.'32

One further aspect that is noticeable throughout the twenty reasons for believing in the existence of God is that the transcendentals of beauty, goodness, and truth keep appearing amongst them in different ways. For Christians, God is the source of these:

All creatures bear a certain resemblance to God, most especially man, created in the image and likeness of God. The manifold perfections of creatures - their truth, their goodness, their beauty all reflect the infinite perfection of God. Consequently we can name God by taking his creatures' perfections as our 
starting point, 'for from the greatness and beauty of created things comes a corresponding perception of their Creator. ${ }^{33}$

The quotation at the end ${ }^{34}$ touches upon the sixteenth reason, Desire when we seek God. The transcendental of beauty is clearly in the seventeenth, and also the fifth and eighth. Of goodness, the links are in the fourteenth and fifteenth, with possibly the ninth. And regarding truth, while the eleventh is most obvious, all the reasons concern the truth because the aim of the professional in such a conversation is to help the recipient regard the existence of God as the truth. The more subjective reasons further attempt to aid the recipient in considering the truth in a more objective way, or at least to consider the relativistic truths to carry some weight, even against his own relative truth.

\section{Conclusion}

It is not an unusual possibility that a Christian professional social worker, carer, or educator could be asked by a client or student to explain why he believes in God, whether looking for reasons to believe, or to support an already existing faith, or even to challenge that belief. Both Scripture and the Second Vatican Council, and in agreement with statements from the Catholic Church's highest positions in recent times, make it clear that the Christian should be ready to respond to such questions in some way, to do so, and for this to be in a Christian manner. Peter Kreeft's contribution in book form as well as his online webpage (Twenty Arguments for the Existence of God) is one source that can be used to prepare for such a conversation, being a source that is not particularly challenging for the non-specialist in this area.

The twenty reasons have been grouped here in three ways: objective, subjective, and a combination of both. This should help the professional to decide which to use depending on the interest of the recipient. There is a certain overlap in some of the reasons and there are times where one from a group may be connected closely with one from another group, showing that the reasons correspond in different ways to different people's pre-existing thoughts, positions, or beliefs. That they all point to God's existence, but in many different ways, can itself be a further argument due to consistency and compatibility.

The professional should not feel an obligation to read and learn all twenty reasons, or to look for more. To be comfortable with reading and passing on several of these in an understandable way is certainly sufficient. Obviously, however, it is better to know more of the reasons and even how they can work together effectively, showing consistency and depth - together, they become a more convincing reason for believing in the existence of God. And if the professional finds the conversation too complex or too detailed, the best action is to admit this and offer to find out the information or to suggest arranging a meeting with another Christian professional or someone from the local church to discuss such matters.

Overall, this article acknowledges that all Christians should be prepared to respond to someone charitably in any setting when asked for a reason to believe in the existence of God. And here, a brief precis of each reason, with some commentary for the Christian, has been offered in order to help in the situation of an encounter with a recipient in a caritas or diakonia setting. While this can be an introduction to this area with commentary on applying Kreeft's twenty arguments, 
the reader is encouraged to read the full offering from Kreeft, just as he himself would encourage reading his own sources further if the reader has such an interest. For, regardless of the interest level, the Church clearly and in different ways calls upon the Christian to be ready to give reasons for believing in the existence of God in a respectful manner reflecting Christian love and service.

\section{Contact}

\section{Stuart Nicolson, MA}

University of South Bohemia in České Budějovice

Faculty of Theology, Department of Philosophy and Religious Studies

Kněžská 8, 37001 České Budějovice

snicolson@tf.jcu.cz 